(i) "This meeting of the Mathematical Association is in favour of a general revision of the syllabus in Mathematics demanded of candidates for the School Certificate examination."

(ii) "This meeting is in favour of a reduction in the number of theorems of which candidates are expected to produce a formal proof and approves of the general principle that the work in Geometry and Trigonometry should be more closely co-ordinated. A more extensive use of three-dimensional ideas and a more practical approach are also desirable."

The third resolution, which found only a few dissentients, was as follows: "This meeting considers that a reduction should be made in the amount of formal Algebra demanded and that the time thus saved should be given to the study of graphs and functionality."

A last resolution, passed by a substantial majority, read : "This meeting would approve the introduction of elementary Calculus, treated principally from a graphical angle, as an optional element in Elementary Mathematics papers".

The remainder of the proceedings on the first day were devoted to papers by Mr. W. W. Sawyer on "The Theory of Functions" and Prof. L. M. MilneThomson on "Harmonic Analysis".

The meeting re-opened on Thursday with a demonstration by Mr. C. W. Hansel of the use of an apparatus consisting of a large mirror mounted at $45^{\circ}$ to the horizontal in the teaching of mathematies. This apparatus allows a class to get a clear view of diagrams and other objects placed in a horizontal plane. A paper on "Infinite Series for Fifth Formers", given by Mr. N. M. Gibbins, concluded the morning session.

The main discussion in the afternoon dealt with a new Higher Certificate mathematical syllabus, drawn up by the Science Masters Association assisted by a number of members of the Mathematical Association. The discussion was opened by Mr. E. H. Lockwood, who gave an account of the events which led to these proposals. He outlined the various levels aimed at in the syllabus, and explained how this syllabus could, by a certain amount of adjustment, be made to fit in with the syllabus required by potential mathematical scholars. In the minimum syllabus, which was planned for a five-term course, emphasis has been placed on calculus and the function idea at the expense of geometry; and elementary rotational dynamics at the expense of more elaborate statics. In the advanced section of the syllabus, the same ideas have been followed out, for example, by the preference of differential equations, determinants, vectors and complex numbers to the usual work on the geometry of conics.

Mr. A. E. E. Mackenzie continued the discussion on behalf of the Science Masters Association, giving some account of the general background and of parallel activities which are being pursued in relation to other branches of science. He referred to widespread criticism from various quarters of the level reached by science students. He considers that the fundamental cause of this criticism is the overloading of the syllabus. An important step in redressing this state of affairs has recently been made in the setting up of advisory committees containing representatives of the teaching associations and some of the examining bodies. These committees, including one dealing with mathematics, have recently approved various proposals with regard to the scholarship syllabuses, and it is hoped that a general co-ordination of the Higher
Certificate syllabuses and the scholarship syllabuses will become an established fact.

Dr. F. C. Powell referred to the genuine feeling existing among university teachers that the time has come to make changes in co-operation with the schools. The new advisory committees would certainly prove valuable in this work. He proceeded to an analysis of some of the points where difficulty has been $\theta x$ per ienced in practice in making a 'clean joint' between school and university work, and welcomed the appearance of differential equations and other parts of the proposed syllabus which would help to eliminate these difficulties.

Mr. C. G. Nobbs reviewed the proposed syllabus in considerable detail and answered certain points raised by previous speakers. He showed how the syllabus has been developed logically from the idea of functionality, and how various parts of the usually accepted mathematical course have been omitted, not because they are not interesting or even useful, but because they do not fit in with this central idea. $\mathrm{He}$ referred to the omission of geometry as being occasioned principally by considerations of time. $\mathrm{He}$ hoped the syllabus would not prove too long and that members would give it a trial.

A large number of members took part in the subsequent discussion, which in the main favoured the new proposals, especially in the 'ordinary' part of the syllabus. A number of speakers referred to the question of undue length, especially for girls. The view was expressed that the advanced syllabus might be abbreviated by a reasonable system of alternatives.

The final paper of the meeting was given by $\mathrm{Mr}$. W. Hope Jones, in his usual entertaining style, the subject being "More Mathematical Geography".

At the business meeting of the Association, Mr. C. O. Tuckey was elected president for 1944 and the other officers were re-elected. The Council's report showed that the Association has well maintained its membership and is in a sound financial condition. Reference was made to the excellent work of Prof. T. A. A. Broadbent in maintaining the standard of the Mathematical Gazette in spite of paper restrictions and other war-time difficulties. A full report of the proceedings will be given, as space permits, in that journal.

\section{CONTROL OF TYPHUS}

$\mathrm{R}$ ECENT references in the daily Press to the appearance of typhus in easterm Europe have prompted a number of questions. What risk is there of outbreaks of typhus among British troops abroad, or of its introduction into Great Britain? What risks will there be of outbreaks of typhus in Europe after the War? Articles in the medical Press show that the whole problem of typhus is being considered all over the world; for typhus is always a serious matter, whether nations are at war or at peace.

At the present time, of course, British troops are contending with an outbreak of typhus in Naples, which has (Brit. Med. J., Feb. 5, 1944, p. 205) become so serious that it is a potential menace to military operations. So far it is confined to civilians. Im. munization by serum has been organized, and some 70,000 civilians a day are being treated for infestation with lice. The outbreak began under German occupa. tion, and has increased since the German destruction of the gas and water supplies, and as a result of 
overcrowding with refugees and others. It is evidently being vigorously attacked.

Some of the risks run by British troops in the Middle East are indicated by abstracts in the Bulletin of War Medicine and by an article by two R.A.M.C. officers, Lieut.-Colonel W. Brockbank and Major S. R. F. Whittaker (The Lancet, Jan. 29, p. 150). According to these authors, although the incidence of typhus is high among civilians in some parts of the Middle East, only sporadic cases have occurred so far among troops there. They describe ten cases, all of whom were British soldiers, which they treated between March and May, 1943. They direct attention to the fact that the early symptoms of typhus may be so like those of malaria, sand-fly fever, relapsing fever or typhoid that a diagnosis when the patient reports sick may be very difficult. The patient may stay for some days in a general ward in a hospital before the diagnosis can be made. Actually eight out of the ten cases described remained in a general ward until the rash of typhus fever appeared on the fifth or sixth day of the illness. The diagnosis was made more difficult by the fact that evidence of the presence of, or contact with, lice was present in only one of the ten cases. Fortunately, no cross-infection occurred. The mortality-rate from typhus is higher in patients more than thirty years old, so that the authors recommend that no personnel older than this should be detailed for duties likely to expose them to contact with typhus. Further, all personnel likely to come into contact with typhus are now given typhus vaccine. The efficacy of the typhus vaccines has been questioned, but Dr. J. B. Penfold, of the Emergency Pathological Service Laboratory, Billericay, reports (Brit. Med. J., Jan. 22, 1944, p. 114) on tests made with a Cox vaccine prepared in Toronto from a European louseborne strain of Rickettsia prowazeki. He vaccinated 23 public health workers with this, and found that the reactions to it were generally slight and local, and that vaccination produced an increase of the agglutination titres in most cases. Drs. Bardhan, Tyagi and Boutros, of No. 12 Field Laboratory, M.E.F., have reported (Brit. Med. J., Feb. 19, 1944, p. 253) on the glass-slide agglutination test for the rapid diagnosis of typhus, modified by them for general use. They urge further trials of this method to establish conclusively the degree of its reliability.

Typhus risks in Europe are discussed by Dr. Yves Biraud, of the Epidemiological Service at Geneva (Bull. Health Org. League of Nations, 10, No. 1 ; 1943. See The Lancet, May 15, 1943, p. 620, and the fuller abstract in the Bulletin of War Medicine, 3, No. 10, $567 ; 1943)$. Dr. Biraud says that typhus has increased in Poland and the Balkans to a disquieting, but not to an alarming, degree since the outbreak of the War. Sporadic foci have also appeared in Germany and Hungary in areas which have been free from the disease; presumably these have been brought from the Eastern front. We may compare this with the outbreaks in German troops of another disease not prevalent in Germany before the War, namely, trichiniasis, which has occurred in Norway and on the Eastern front. Sporadic foci of typhus have also been found in central and southern France; but almost all the cases in these areas have been people arriving from North Africa, where the disease is always present. Bad economic conditions, such as those which resulted from the fall of France, increased its incidence in North Africa. It is not surprising that the incidence in 1941 was more than twice that recorded for any of the preceding twenty years, and that the 1941 figures were exceeded in the early months of 1942 .

Typhus in Iran was the subject of an address by Col. Faruqi, I.M.S., to the recently formed AngloIranian Medical Society (Brit. Med. J., Dec. 25, 1943, p. 820). Last year, said Col. Faruqi, typhus killed many people and he feared a much more serious epidemic. He explained that there are plenty of medical men with wide experience of typhus now in Iran, but suggested the formation of a committee to control preventive work and to co-ordinate information.

In Spain the typhus epidemic of 1908-9 stimulated intensive study of the treatment and prevention of the disease. An account of the modern methods now being used in Madrid is given by Prof. Clavero del Campo, director of the National Institute of Health, and Dr. Perez Gallardo in a monograph entitled "Técnicas de Laboratorio en el Tifus Exantemático". This is an official publication of the Direccion General de Sanidad, Madrid, and was published in 1943. To it the director-general of health, Prof. J. A. Palanca, contributes an introduction which outlines the measures taken against these two epidemics and indicates the areas invaded by the disease. After the epidemic of 1908-9, he says, sporadic cases occurred in Spain until the epidemic of 1941-42 began. While it is as yet too early, he thinks, to claim that the latter epidemic has been conquered, it has been controlled. His account of the difficulties encountered and the measures taken shows that full advantage is being taken of the experience of specialists in other countries and of the experience gained by Dr. Gallardo when he was sent to laboratories in Germany, Poland and elsewhere. Such difficulties as the destruction by war of the National Institute of Health and the modern Rockefeller Virus Department might have daunted any but the most persistent and enthusiastic workers.

In another paper Prof. Clavero and Dr. Gallardo give the results of their work on a strain of $R$. prowazeki originally isolated and cultivated by the Cox technique on chick embryos by Dr. Snyder in 1941, and on a variant of this strain which has lost its patho. genicity, yet has retained its immunizing power (Revista de Sanidad e Higiene Publica, Madrid, June 1943). In further papers they report on their work on Giroud's intradermal test for typhus infection (ibid., Dec. 1942) and on their investigation (ibid., May 1943) of 384 rats and 62 fleas in Madrid, from which they conclude that a murine virus does not exist in the rats of Madrid. They discuss the errors which may arise from the presence in rats of various bacterial infections (Salmonella enteritidis, $B$. alcaligenes broncho-septicus, Spirochætes, etc.). We have already referred to the work of other Spanish medical men on typhus in some of the Latin-American countries: in Venezuela, for example (Nature, Jan. 8, 1944, p. 51), and Bolivia (NATuRe, Feb. 5, 1944, p. 162). The existence of endemic typhus in Bogotá, Colombia, is reported by Prof. Luis Patiño-Carmago (Rev. de la Facultad de Medicina, Bogotá, 11, 503; 1943), who claims that eight strains of the Rickettsia type have been found in various parts of Colombia. The pages of this journal and of the Boletin de la Oficina Sanitaria Panamericana show that typhus is being carefully watched and combated throughout Latin and North America.

Finally, reference may be made to an annotation in The Lancet (May 1, 1943, p. 562) which discusses the precautions taken against the entry of typhus 
into the British Isles. Control depends on the control of the head or body louse infected with $R$. prowazeki, on prompt isolation of patients and contacts, delousing, disinfection of both the premises of the patients and the contacts, and on other measures which can only be carried out effectively by specially trained personnel. These personnel must be themselves protected (by protective clothing, vaccination, etc.). In England such mobile anti-typhus squads were formed some time ago. The shortage of nursing personnel made it difficult to provide suitable people for this duty, because they must be young (see above) ; but plenty of volunteers were available. At the same time, many authorities earmarked suitable sections of isolation hospitals for possible typhus cases. Such measures as these, combined with the strict watch which is kept at ports of entry and on aeroplanes, indicate that the risk of the entry of typhus into the British Isles is not being neglected. G. LAPAGE.

\section{FORTHCOMING EVENTS}

Friday, April 28-Sunday, April 30

INSTITUTE of INDUSTRIAL ADMINISTRATION (at the Waldorf Hotel Aldwych, London, W.C.2). Conference on "Management and Scciety".

\section{Saturday, April 29}

British RHEologists' CLUB (at the Shirley Institute, Didsbury, Manchester), at 10 a.m. -Discussion on "Elastic Behaviour of Textile Materials".

Association fror Scientifio Photography (at the Caxton Hall, Westminster, London, S.W.1), at 2.30 p.m.- "Photography as a Tool
in Agriculture" (Papers will be read by Dr. E. N. Crook and Mr. V. in Agriculture" (Papers will be read by Dr. E. N. Crook and Mr. V. Agricultural Engineering).

PHysical SocIETy (at the new Clarendon Laboratory, Oxford), at 2.30 p.m.- Prof. Joel H. Hildebrand : "The Liquid State" (Twentyeighth Guthrie Lecture).

\section{Monday, May I}

SocIETY of Engineers (at the Geological Society, Burlington House, Piccadilly, London, W.1), at 5 p.m.-Mr. R. H. Bound: "Aircraft Hydraulic Equipment"

INSTITUTION OF EleCTRICAI, ENGINEERS (CAMBRIDGE AND DISTRICT WrReless Group) (at the Technical School, Cambridge), at $5.30 \mathrm{p.m}$. Mr. C. R. Stoner and Mr. R. W. Wilson: Discussion on "Training for the Radio Industry".

\section{Tuesday, May 2}

SheFFiedd Metalludgical Association (at 198 west Street Sheffield 1), at 6.30 p.m.-Mr. J. S. Ridges: "The Work of the Iron and Steel Control"

\section{Wednesday, May 3}

Socinty of Public Analysts and other Analytical Chemists (at the Chemical Society, Burlington House, Piccadilly, London, W.1), at 5 p.m.- Scientiflc Papers.

INSTITUTION OF ELECTRICAI ENGINEERS (WIRELESS SECTION) (at Silver Jubilee Commemoration Meeting.

\section{Thursday, May 4}

INSTITUTE OF Physrcs (ELECTRONICS GROJP) (at the Royal Society, Burlington House, Piccadilly, London, W.1), at 5.30 p.m.-Mr. L. G. Grimmett:; "The Electrostatic Generator, its Development and Prospects;".

Institution of Electrical ENgineers (INstallations Section) (at Savoy Place, Victoria Embankment, London, W.C.2), at 5.30 p.m. of Domestic Eiectric Appliances".

\section{Friday, May 5}

GEologists' Assodiation (at the Geological Society of London Burlington House, Piccadilly, London, W.1), at 5.30 p.m.-Mr. A. S Kennard: "The Crayford Brickearths".

\section{APPOINTMENTS VACANT}

Applicatrons are invited for the following appointments on or before the dates mencioned :

LECTORER IN THE MECHANICAL AND CIVIL ENGINEERING DEPARTMENT -The Registrar, Technical College, Srunderland (May 5).

SECRETARY (temporary) of the Department of Agriculture-The Acting Registrar, The University, Leeds 2 (May 6).

Permanent BIOLOGIST (male or female) in the Public Health Department-The Medical Officer of Health, Town Hall, Luton (May 8).
Eddcational Psychologist (full-time), and a Psyohiatrio Social WORKER (full-time) - The Director and Secretary, Education Offices, Brettenham Road, Edmonton, London, N.18 (May 8).

TECHNICAL OFFICER ro advise on questions of cropping and manuring of arable land and the management of dairy stock-The Secretary, Berkshire War'Agricultural Executive Committee, 1 Abbot's Walk, Reading (May 8).

LECTURER (full-time) IN ELECTRICAL ENGINEERING at the Lancaster Technical College-The Director of Education, High Street House, Lancaster (May 8).

PRINCIPal of THE Blackpool and Fylde TeOhNical ColLegeThe Director of Education, 3 Caunce Street, Blackpogl (May 8).

DRUMMOND PROFESSORSHIP OF POLITICAL ECONOMY-The Registrar,

University Registry, Oxford (May 13).
UNIVERSITY READFRSIP IN CHEMICAL PAThology tenable at University College Hospitai Medical School-The Academic Registrar, University of London, at Richmond College, Richmond, Surrey (May 15).

LedTurer in Science and Elementary Engineering SUbJectsThe Principal, County Technical College, Worksop, Notts. (May 15). ENGINEERING INSPEOTOR OF MINES (temporary) in a Government 432, Alexandra House, Kingsway, London, W.C.2 (quoting Reference No. C.2088A) (May 17).

W. H. Collins Professorship of Human and Comparative PATHoLogy-The Secretary, Royal College of Surgeons of England, ncoln's Inn Fields, London, W. C.2 (July 31).

SENIOR LECTURESHIP IN THE DEPARTMENT OF METALLURGY of the University of the Witwatersrand Place, London, E.C.2 (July 31)

CHIEF ENGINEER AND GENGRAL MANAGER of the Gloucester ElecCity Undertaking - The Town Clerk, Guildhall, Gloucester.

GRADUATE LECTURER IN ElECTRICAI. ENGINEERING at the Southendon-Sea Municipal College-The Chief Education Officer, Education Office, Warrior Square, Southend-on-Sea.

LECTURER (full-time) IN MATHEMATICS-The Registrar, Municipal College, Portsmouth.

LECTURER (temporary) in MECHANICAL ENGINEERING-The Principal, Handsworth Technical College, Golds Hill Road, Handsworth, Birmingham 21.

PHYsicist to the Newcastle-upon-Tyne National Radium Centre-Dr. A. W. Sanderson, Secretary of Newcastle-upon-Tyne National Radium Centre, Royal Victoria Inftrmary, Newcastle-upon-Tyne.

\section{REPORTS and other PUBLICATIONS (not included in the monthly Books Supplement)} Great Britain and Ireland

Institution of Mining and Metallurgy. Memorandum to the Minister of Reconstruction on the Production of Non-Ferrous Metals and Minerals other than Coal in Great Britain. Pp. 12. (London : InstituMinerals other than Coal in Great Britain. Pp. 12. (London : Institu-
[243 Imperial Institute. Annual Report, 1943, by the Director, Sir Harry Lindsay, to the Board of Governors. Pp. 62. (London : Imperial Harry Lindsay,
Institute.)
[44 Boron and Plant Life. Part 5 : Developments in Agriculture and Horticulture, 1940-42. By A. C. Dennis and Dr. R. W. G. Dennis. Pp. 38. (St. Albans : Boron Agricultural Bureau.) Conditions for Industrial Health and Efficiency. Pamphlet No. 2 :
Absence from Work; Prevention of Fatigue. Pp. 20. (London : Absence from Work; Prevention of Fatigue. Pp. 20. (London : H.M. Stationery Office.) $3 d$. net.
Ministry of Health and Department of Health for Scotland. Venereal Ministry of Health and Department of Health for Scotland. Venereal Disease: Guide for Practitioners working under the Provisions of Ministry of Health Circular 2226 and Department of Health for
Scotland Circular No. 50/1941. By L. W. Harrison. Pp. 20. (London : Ministry of Health.)

\section{Other Countries}

University of California Publications in Zoology. Vol. 46, No. 7 : Two New Subspecies of Kangaroo Rats (Genus Dipodomys) from Southern California. By Jean T. Boulware. Pp. 391-396. 25 cents. Vol. 48, No.2: Systematic Review of the Chipmunks (Genus Eutamias) of California. By David H. Johnson. Pp. 63-148+plate 6. 1 dollar. (Berkeley and Los Angeles: University of California Press; London: Cambridge University Press.) (- [313 The Aborigines-'so-called'-and their Future. By Prof. G. S. Ghurye. (Gokhale Institute of Politics and Economics, Publication Economics.) 8 rupees: $16 s$.

Society of Biological Chemists, India. Annual Review of Biochemical and Allied Research in India. Vol. 13 for 1942. Pp. xiii +101 . (Bangalore: Society of Biological Chemists, India.) 3 rupees ; 68. [44 Bulletin of the Illinois Natural History Society. Vol. 22, Art. 2 : Studies of North American Plecoptera, with Special Reference to the Fauna of Illinois. By T. H. Frison. Pp. iv $+235-356.1$ dollar. Vol. 22, Art. 3: Management of Small Artiflcial Lakes, a Summary of iv $+357-376$. Vol. 22, Arts. 4-5: The Prairie Chicken in Illinois, by iv $+357-376$. Vol. 22, Arts. 4-5 The Prairie Chicken in rilinois, by Ralph E. Yeatter; Preferential Rating of Duck Food Plants, by 22, Arts. 6-7: Survey of the Mlinois Fur Resource, by Louis G. Brown and Lee E. Yeager ; Illinois Furbearer Distribution and Income, by Carl O. Mohr. Pp. vi+435-538. (Urbana, Ill.: Illinois Natural [44
History Society.) National Research Council of Canada. Modern Plotting InstruNational Research Council of Canada.) 1.50 dollars.

\section{Catalogues}

Scientific Centenaries in 1943 and 1944, Books from an Astronomer's Library, Documents and Instruments, History of Photography. (Catalogue 4.) Pp. 36. (I,ondon: E. Weil.) $2 d$. 